\title{
Albumin nanoparticles loaded with the antitumor drug «Hydroxycarbamide» by the incorporation method
}

\begin{abstract}
In this article the possibility of loading the antitumor drug «Hydroxycarbamide» into the polymeric matrix of human serum albumin was studied. Nanoparticles of serum albumin were obtained using desolvation method. Prepared empty human serum albumin nanoparticles have average size of $108.4 \mathrm{~nm}$ with narrow particle size distribution, which make them promising in using for the drug delivery purposes. The binding of hydroxycarbamide with the polymer was performed by incorporation of the drug into the medium during the process of crosslinking of albumin macromolecules. Incorporation of the drug into human serum albumin led to the formation of nanoparticles loaded with hydroxycarbamide with satisfactory physico-chemical characteristics (average particle diameters were in the range of $250-350 \mathrm{~nm}$ and the value of polydispersity index was $0.2-0.3$ ) with the high value of binding degree (up to $68 \%$ ). It was shown that increasing the concentration of the drug in the initial solution led to the increase of binding degree of hydroxycarbamide with human serum albumin nanoparticles. The kinetics of release process of the drug from albumin nanoparticles in the conditions modeling biological medium was studied. As a result of the study of the drug release rate it has been concluded that prolonged release of hydroxycarbamide can be achieved when nanosomal form of the drug is used.
\end{abstract}

Keywords: nanoparticles, human serum albumin, desolvation, antitumor drug, Hydroxycarbamide, incorporation, loading, drug delivery, polymers.

\section{Introduction}

Nowadays it is known that the use of prolonged drug dosage forms or «prodrugs» instead of traditional ones have several advantages in comparison with conventional drug delivery systems. First of all it is defined by the increase of therapeutic efficiency of biologically active substance, which takes place due to the localization of needed concentration of drug in the targeted organ or tissue, thus leading to prolongation of the drug effect. Optimization of the effect of drug preparations can be accomplished by «construction» of drug dosage forms on micro- and nano-level on the basis of the polymers, which have wide application in medicine. Among the biocompatible and biodegradable polymers, which can be used as a polymeric basis for developing «prodrugs», a serum albumin is of great interest $[1,2]$. For the last decade human serum albumin (HSA) is used as a good transporting agent especially for low molecular compounds including drug preparations. There are known some novel systems in the forms of nanoparticles based on HSA for such drugs of protein origin as «Albuferon» and «Levemir» [2,3]. Besides, the in vivo studies of toxic effects of nanosomal formulations of albumin for the controlled delivery of antitumor drugs have shown the decrease of side effects $[2,3]$. "Abraxane» is the example of effective using HSA nanoparticles in tumor chemotherapy [3]. «Abraxane» is the nanoparticulate form of antitumor drug «Paclitaxel» on the basis of albumin and it was approved for the treatment of breast tumor [3]. So HSA nanoparticles allow increasing the solubility of drug preparations, thus improving their uptake by tumor cells.

In this regard, the goal of this work was to study the possibility of binding HSA nanoparticles with antitumor drug preparation «Hydroxycarbamide» with the aim of prolongation of its theraputic efficiency and decreasing undesired toxic effects.

\section{Method}

\section{Preparation of empty and drug loaded HSA nanoparticles}

Empty HSA nanoparticles were prepared using a desolvation method $[4,5]$. Briefly, the $\mathrm{pH}$ of HSA solution of albumin ( $2 \%)$ was adjusted to 8.3 with buffer solution. Then under constant stirring $(600 \mathrm{rpm})$ at room temperature $8 \mathrm{ml}$ of ethanol $(96 \%)$ was added to the mixture $(1 \mathrm{ml} / \mathrm{min})$ using a tubing pump. After the desolvation process the particles were stabilized by the addition of an aqueous $8 \%$ glutaraldehyde solution $(1.175 \mu \mathrm{l}$ per $\mathrm{ml} \mathrm{HSA})$. After that the suspension was stirred for $24 \mathrm{~h}$. The nanoparticles were separated 
from low molecular components by repeated centrifugation with the Centrifuge MiniSpin Plus 14500 (Eppendorf, Hamburg, Germany) at 14500 rpm and washing them with water.

HSA nanoparticles loaded with the antitumor drug hydroxycarbamide were obtained using the same procedure with the difference that the drug was dissolved in the solution of albumin before carrying out the process of desolvation. The yield of nanoparticles was determined by gravimetric method.

Measurement of particle size and polydispersity

The average particle size and polydispersity index (PDI) were measured by photon correlation spectroscopy (PCS) using a Malvern Zetasizer Nano 90S (Malvern Instruments Ltd., Malvern, UK) at a temperature $25^{\circ} \mathrm{C}$ and at a scattering angle $90^{\circ}$.

Pictures of empty HSA nanoparticles and nanoparticles loaded with hydroxycarbamide were made by electron microscopy on MIRA 3 LM TESCAN (Czech Republic).

Study of binding and drug release of hydroxycarbamide from HSA nanoparticles

The binding of hydroxycarbamide with nanoparticles was determined from the concentration of drug in the supernatant solution. The analysis of supernatant solution was made on UV-1800 SHIMADZU by UVspectrophotometry $(\lambda=214 \mathrm{~nm})$. Before measurement the solutions were diluted with water.

The study of in vitro drug release was performed in PBS solution ( $\mathrm{pH} 7.4)$ at $37^{\circ} \mathrm{C}$ within 24 hours. The samples were withdrawn from a beaker and analyzed by UV-spectrophotometry $(\lambda=214 \mathrm{~nm})$.

\section{Results and discussion}

Empty HSA nanoparticles have been obtained using desolvation method described above. Physicochemical characteristics (average particle diameter and particle size distribution) are shown in Figure 1. The results of dinamyc light scattering demonstrate that the size of the particles is less than $150 \mathrm{~nm}$ and PDI is equal to 0.273 . From the given figure it is also clear that there is small amount of big particles of microne size in the system, which were separated from the emulsion by centrifugation at low rate $(3000 \mathrm{rpm})$. Overall obtained HSA nanoparticles have satisfactory parameters, therefore they are applicable as transporting systems for drug preparations.

\begin{tabular}{|c|c|c|c|c|}
\hline & & Size (d.nm): & $\%$ Intensity & Width (d.nm) \\
\hline Z-Average (d.nm): 108,4 & Peak 1: & 117,2 & 91,9 & 53,24 \\
\hline Pdl: 0,273 & Peak 2: & 3533 & 8,1 & 1223 \\
\hline Intercept: 0,639 & Peak 3: & 0,000 & 0,0 & 0,000 \\
\hline
\end{tabular}

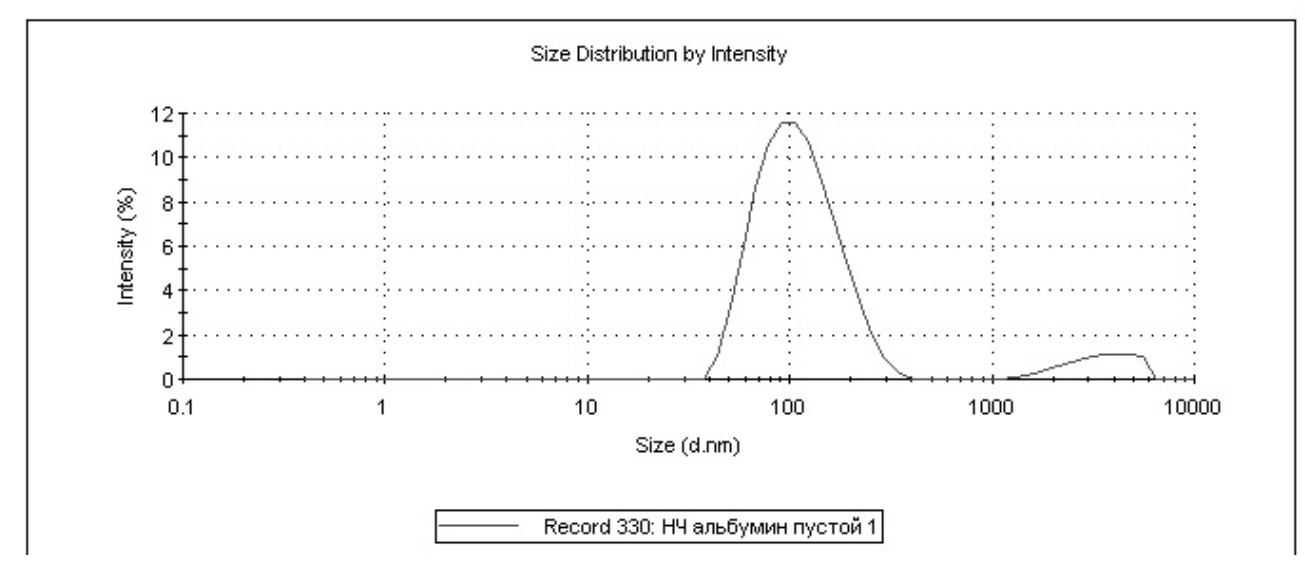

Figure 1. Particle size distribution of empty HSA nanoparticles

The immobilization of HSA nanoparticles with the drug were performed by incorporation of the drug into the medium during the process of macromolecules crosslinking. An incorporation of the drug into the system when the nanoparticles are formed allow to achieve high loading. The loading of HSA with hydroxycarbamide was performed using three concentrations $(0.217 \mathrm{mg} / \mathrm{ml}, 0.326 \mathrm{mg} / \mathrm{ml}$ and $0.484 \mathrm{mg} / \mathrm{ml})$ of the drug. Obtained drug loaded HSA nanoparticles were characterized by photon correlation spectroscopy (PCS), the results are presented in Figure 2 and in Table. 


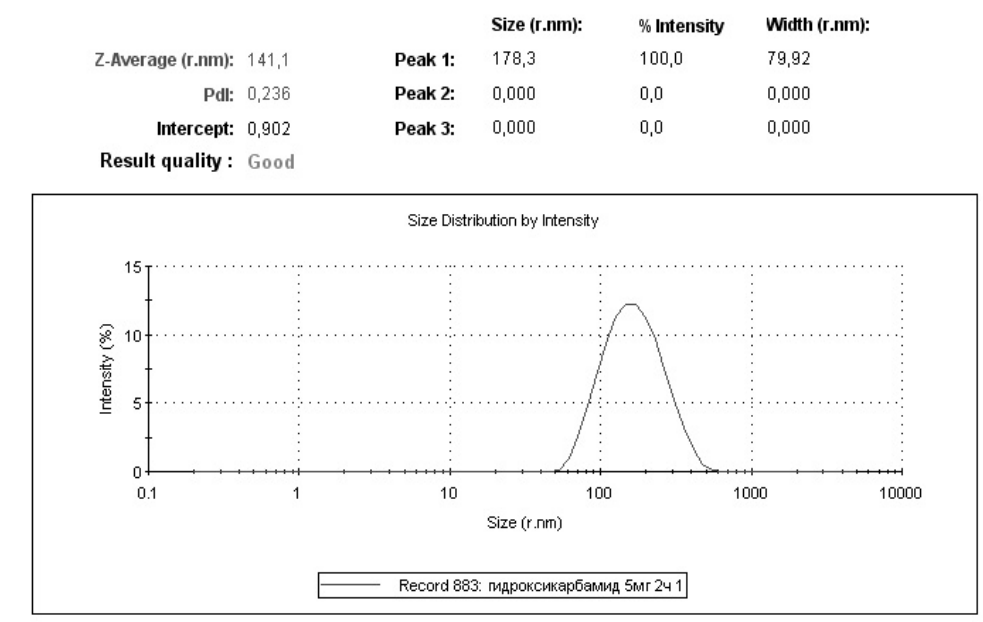

a)

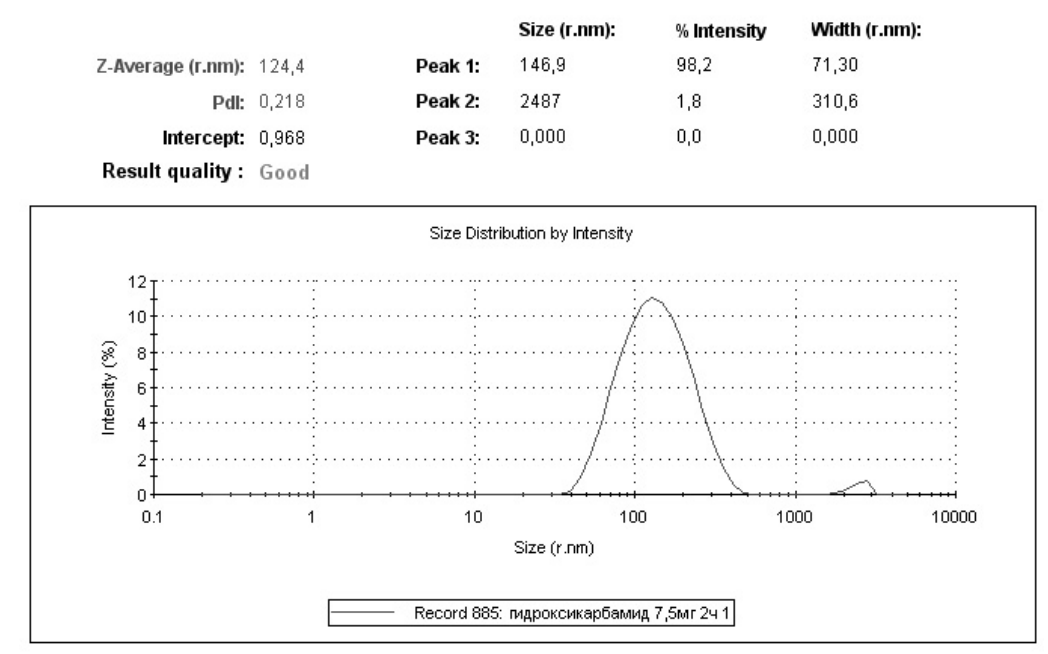

b)

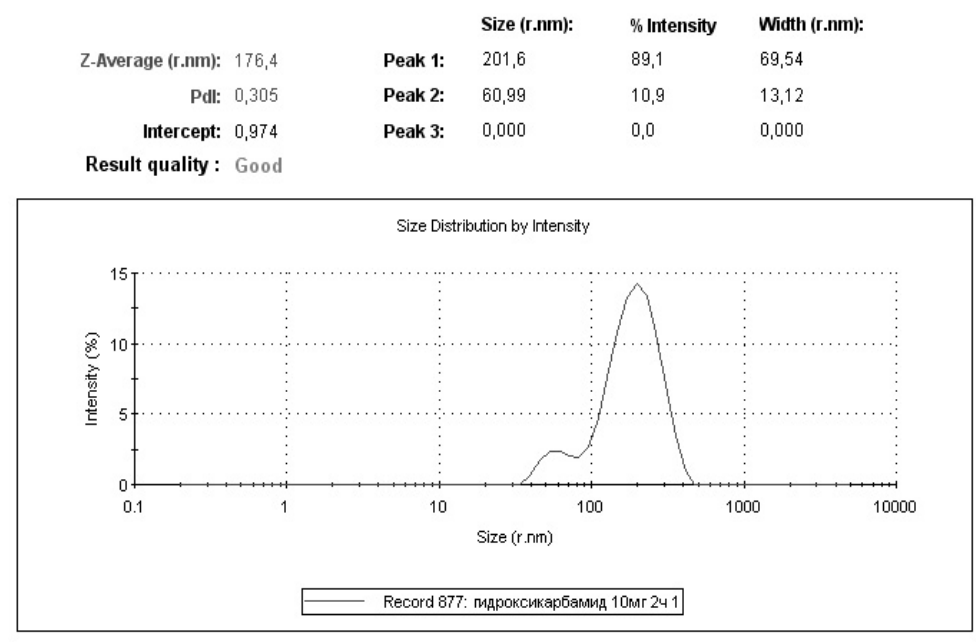

c)

$a-0.217 \mathrm{mg} / \mathrm{ml} ; b-0.326 \mathrm{mg} / \mathrm{ml} ; c-0.484 \mathrm{mg} / \mathrm{ml}$

Figure 2. Particle size distribution of drug loaded HSA nanoparticles at various concentrations of the drug 
Physico-chemical characteristics of HSA nanoparticles loaded with hydroxycarbamide

\begin{tabular}{|c|c|c|c|c|c|}
\hline \multirow[b]{2}{*}{$C_{\text {Hydrox }}, \mathrm{mg} / \mathrm{ml}$} & \multicolumn{3}{|c|}{ Characteristics of nanoparticles } & \multirow[b]{2}{*}{ Binding degree, $\%$} & \multirow[b]{2}{*}{$\begin{array}{c}\text { Yield of } \\
\text { nanoparticles, \% }\end{array}$} \\
\hline & $\begin{array}{l}\text { Average particle } \\
\text { diameter, } d, \mathrm{~nm}\end{array}$ & PDI & $\begin{array}{c}\text { Fraction of } \\
\text { nanoparticles, } \%\end{array}$ & & \\
\hline 0 & 108.4 & 0.273 & 91.9 & - & 93.3 \\
\hline 0.217 & 282.2 & 0.236 & 100.0 & 13.52 & 84.97 \\
\hline 0.326 & 248.8 & 0.218 & 98.2 & 35.13 & 85.68 \\
\hline 0.484 & 352.8 & 0.305 & 89.1 & 67.56 & 86.75 \\
\hline
\end{tabular}

From the graphs it can be seen that the average particle size of nanoparticles ranges between 250 $350 \mathrm{~nm}$ which is suitable size for the drug delivery systems. The data presented in the table also show that the yields of nanoparticles are also high (84-87\%).

It is important to know the quantity of the drug bond to nanoparticles, which defines the possibility of using particles obtained for the drug delivery purposes. Therefore the binding degree of HSA nanoparticles with hydroxycarbamide was determined using UV-spectroscopy. As it is clear from the table the values of binding degree and the yields of nanoparticles gradually increase with the increasing the concentration of hydroxycarbamide, that means that the amount of the drug can be considerably increased.

The surface and morphology of obtained HSA nanoparticles were observed on MIRA 3 LM TESCAN electron microscope (Czech Republic) (Fig. 3).

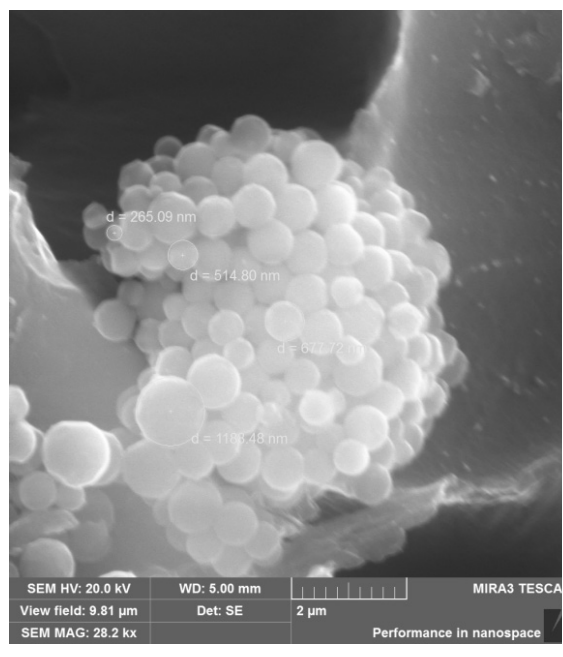

$a$

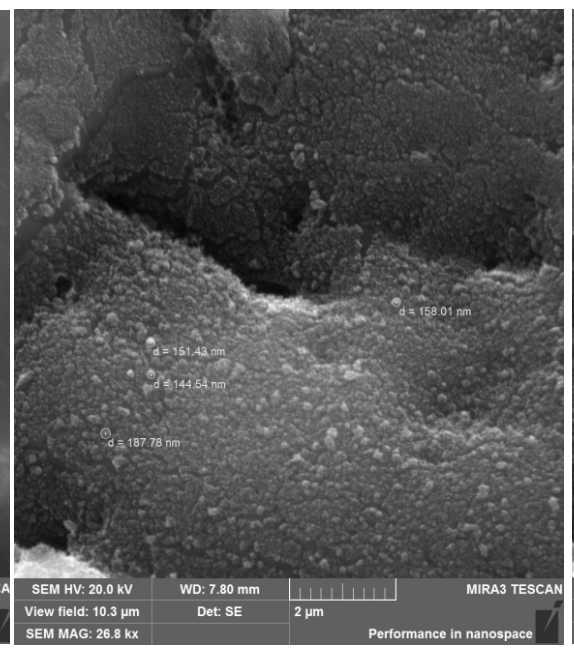

$b$

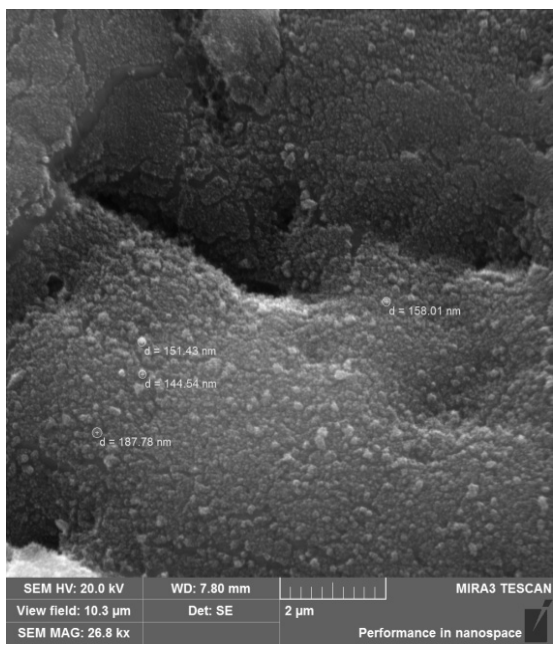

$c$

$a-0.217 \mathrm{mg} / \mathrm{ml} ; b-0.326 \mathrm{mg} / \mathrm{ml} ; c-0.484 \mathrm{mg} / \mathrm{ml}$

Figure 3. REM pictures of HSA nanoparticles loaded with hydroxycarbamide at various concentrations

From the given pictures it can be judged that the results of electron microscopy have well correspondence with the results obtained by PCS: HSA nanoparticles loaded with hydroxycarbamide have smooth surface and round shape without any inclusions (Fig. 3). Mainly all three systems consist of the particles of similar size in the interval of 150-300 nm, however bigger particles with the size more than $500 \mathrm{~nm}$ also present in the system.

The study of the kinetics of drug release is of great importance as it determines the applicability of prepared HSA nanoparticles loaded with the drug in a treatment of tumor disease. Therefore the release rate of hydroxycarbamide from HSA nanoparticles was observed under in vitro conditions $\left(\mathrm{pH} 7.4\right.$ and $\mathrm{T}=37^{\circ} \mathrm{C}$ ) within 24 hours. The results of the study are given on the graph below (Fig. 4). 


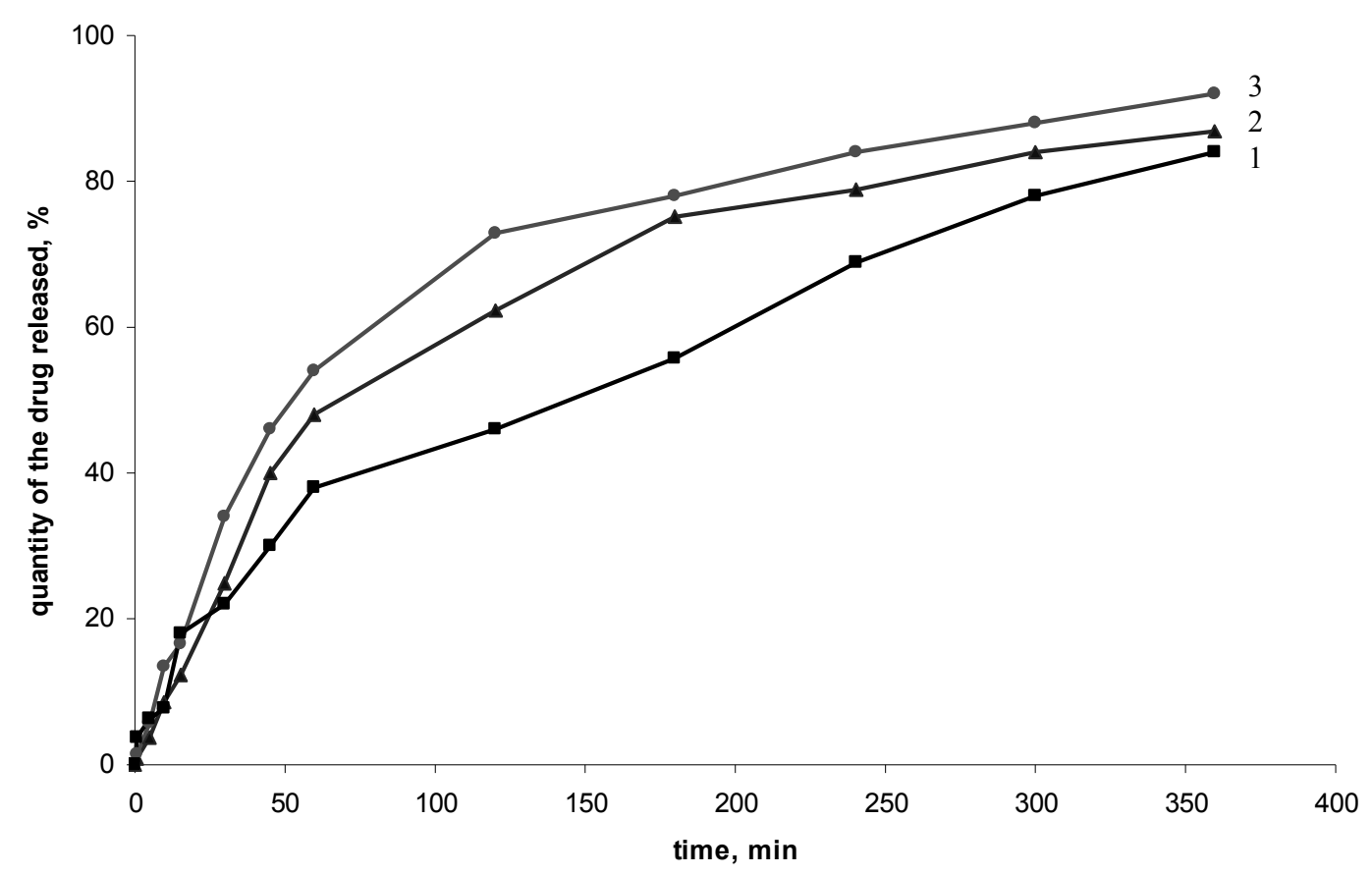

Initial concentrations of the drug are: $1-0.217 \mathrm{mg} / \mathrm{ml} ; 2-0.326 \mathrm{mg} / \mathrm{ml} ; 3-0.484 \mathrm{mg} / \mathrm{ml}$

Figure 4. Release of hydroxycarbamide from HSA nanoparticles

The curves on drug release demonstrate that the higher the amount of hydroxycarbamide bond to nanoparticles the faster the process goes. So at a minimal concentration of the drug (1) the release takes place rather slow whereas when loading HSA nanoparticles with the higher quantity of hydroxycarbamide, it is clearly seen that $50 \%$ of the drug releases to the medium within $60-150$ minutes depending on the amount of loaded drug (Fig. 4). However in general it can be concluded that the release rate of hydroxycarbamide from HSA nanoparticles is rather low as in all three cases, i.e. less than $80 \%$ of the loaded drug eliminates to the surrounding medium within 3 hours. It is seen from the graph that after 6 hours approximetaly 80-90\% of the loaded hydroxycarbamide releases from the matrix of nanoparticles. After that time however the release of the rest part of the drug was not observed which is quite regular for this kind of systems and it can be explained by the retardation of elimination caused by crosslinked structure of albumin macromolecules which does not allow to the molecules of the drug to be released outside from the inner part of HSA nanoparticles.

\section{Conclusions}

So as a result of the study HSA nanoparticles loaded with antitumor drug «Hydroxycarbamide» by incorporation of the drug during the process of macromolecules crosslinking were obtained. Nanoparticles synthesized have satisfactory characteristics and rather long release rate, which make them promising systems for the drug delivery purposes.

\section{References}

1 Kreuter, J. (1994). Nanoparticles: Colloidal Drug Delivery Systems. New-York: Marcel Dekker, USA.

2 Kratz, F. (2008). Albumin as a drug carrier: Design of prodrugs, drug conjugates and nanoparticles. J. Cont. Rel. 132, 171183.

3 Kreuter, J. (2007). Nanoparticles - a historical Perspectives. Int. J. Pharm., 331, 1-10.

4 Dreis, S., Rothweiler, F., \& Michaelis M., et al. (2007). Preparation, characterization and maintenance of drug efficacy of doxorubicin-loaded human serum albumin nanoparticles. Int. J. Pharm., 341, 207-214.

5 Langer, K., Balthasar, S., \& Vogel, V., et al. (2003). Optimization of the preparation process for human serum albumin nanoparticles. Int. J. Pharm., 257, 169-180. 
Е.М. Тажбаев, М.Ж. Буркеев, Л.Ж. Жапарова, Т.С. Жұмағалиева, А.А. Ағдарбек

\title{
Қатерлі ісікке қарсы «Гидроксикарбамид» препаратымен енгізу әдісімен иммобилденген альбуминді нанобөлшектер
}

\begin{abstract}
Мақалада қатерлі ісікке қарсы «Гидроксикарбамид» препаратын адамның сарысулы альбуминінен алынған нанобөлшектерге иммобилдеу мүмкіндігі зерттелді. Адамның сарысулы альбуминді нанобөлшектері десольваттау әдісімен алынды. Синтезделген альбуминді нанобөлшектердің орташа өлшемі 108,4 нм және өлшем бойынша таралуы тар болды. Бұл оларды алдағы уақытта дәрілік заттарды тасымалдауда қолдануға мүмкіндік береді. Дәрілік затты полимермен байланыстыру гидроксикарбамидті ортаға альбуминді нанобөлшектердің түзілуі барысында енгізілуі арқылы жүзеге асырылды. Дәрілік затты альбуминмен енгізу әдісімен байланыстыру қанағаттанарлық сипаттамаларға ие (бөлшектердің орташа өлшемі 250-350 нм, ал полидисперсті мәндері 0,2-0,3) және байланысу дәрежесі жоғары (68\%-ға дейін) гидроксикарбамидпен иммобилденген сарысулы альбуминді нанобөлшектердің түзілуіне әкелді. Бастапқы ерітіндіге енгізілген дәрілік заттың концентрациясын арттыру гидроксикарбамидтің альбуминді нанобөлшектермен байланысу дәрежесінің артуына әкелетіні көрсетілді. Биологиялық шарттарды модельдейтін жағдайда дәрінің альбуминді нанобөлшектерден босап шығу кинетикасы зерттелді. Гидроксикарбамидтің альбуминді нанобөлшектерден босап шығу үрдісін зерттеу нәтижесінде дәрілік препараттың наносомалы үлгісін қолдану арқылы дәрілік заттың ұзағырақ уақыт аралығында босап шығуына қолжеткізуге болатыны туралы қорытынды жасалды.
\end{abstract}

Кілт сөздер: нанобөлшектер, адамның сарысулы альбумині, десольвация, гидроксикарбамид, енгізу, иммобилдеу, дәрілерді тасымалдау, полимерлер.

Е.М. Тажбаев, М.Ж. Буркеев, Л.Ж. Жапарова, Т.С. Жумагалиева, А.А. Агдарбек

\section{Наночастицы альбумина, иммобилизованные противоопухолевым препаратом «Гидроксикарбамид» методом включения}

\begin{abstract}
В статье изучена возможность иммобилизации противоопухолевого препарата «Гидроксикарбамид» в матрицу наночастиц человеческого сывороточного альбумина. Наночастицы человеческого сывороточного альбумина получали методом десольвации. Полученные наночастицы альбумина имеют средний размер 108,4 нм с узким распределением частиц по размерам, что делает их перспективными при использовании в доставке лекарств. Связывание лекарственного вещества с полимером проведено непосредственным введением гидроксикарбамида в среду в процессе сшивки макромолекул альбумина. Включение лекарственного вещества в наночастицы человеческого сывороточного альбумина привело к образованию наночастиц, иммобилизованных гидроксикарбамидом, с удовлетворительными физико-химическими характеристиками (средний размер частиц составил 250-350 нм, а значения полидисперсности - 0,2-0,3) и высокими значениями степени связывания (до 68 \%). Показано, что увеличение концентрации лекарственного вещества, введенного в первоначальный раствор, приводит к увеличению степени связывания гидроксикарбамида с наночастицами сывороточного альбумина. Исследована кинетика процесса высвобождения лекарства из наночастиц альбумина в условиях, моделирующих биологические. По результатам изучения процесса высвобождения гидроксикарбамида из наночастиц альбумина сделан вывод о том, что можно добиться более длительного высвобождения лекарства при использовании наносомальной формы лекарственного препарата.
\end{abstract}

Ключевые слова: наночастицы, сывороточный альбумин человека, десольвация, гидроксикарбамид, включение, иммобилизация, доставка лекарств, полимеры. 